\title{
ВІТРОВА ЕНЕРГЕТИКА УКРАЇНИ: ПОДАЛЬШИЙ РОЗВИТОК СЕКТОРА НА РИНКОВИХ УМОВАХ
}

А.С. Конеченков, голова правління ГС «Українська вітроенергетична асоціація»,

К.О. Книш, магістр, керівник аналітичного департаменту ГС «Українська вітроенергетична асоціація», член Громадської Ради при Державному агентстві з енергоефективності та енергозбереження України

Громадська спілка «Українська вітроенергетична асоціація»,

01015, вул. Лаврська 20, оф. 316, Київ, Україна

Вітроенергетичні технології відіграють одну з ключових ролей в глобальному «зеленому» енергетичному переході й боротьбі зі змінами клімату, а віднедавна, ще й виступають дієвим інструментом подолання економічних наслідків пандемії COVID-19. Виконання взятих на себе міжнародних зобов'язань і досягнення національних иілей з розвитку відновлюваних джерел енергії неможливе без структурованої держсвницької позиції та ефективних механізмів стимулювання проєктів ВДЕ. Сучасними світовими політичними інструментами підтримки відновлюваних джерел енергії загалом та вітрової енергетики зокрема є регуляторна політика, податкові стимули та державна підтримка. Всі ијі інструменти на практиці реалізуються у вигляді окремих механізмів підтримки, які використовуються крайнами відповідно до їх енергетичної спроможності, політичної зрілості та економічної розвиненості. Згідно з чинним законодавством України нові вітроенергетичні проєкти, введені в експлуатацію після 2022 року, не зможуть отримати «зелений» тариф. Саме тому перехід від «зеленого» тарифу до альтернативних механізмів підтримки є логічним наступним кроком у розвитку начіонального вітроенергетичного сектора та розбудови безвуглецевої економіки Украйни. Враховуючи украӥнський контекст, розглядається потенціал запровадження одного або комплексу таких альтернативних систем підтримки сектору ВДЕ як, зокрема, «зелені» сертифікати, «зелені» надбавки (англ. Fееd-іп рrетіuтs), контракти на різницю (англ. Contract for difference), аукиіони, прямі договори купівлі-продажу електроенергї (англ. Согрогаtе PРAs) та гарантії походження електроенергії. Так, першим кроком до оновлення системи підтримки ВДЕ в Україні стало представлення Міністерством енергетики України в серпні 2021 року законопроекту «Про внесення змін до деяких законів України щьдо стимулювання виробництва електричної енергї з альтернативних джерел енергї на ринкових засадах , який пропонує новий механізм підтримки виробників електроенергії з відновлюваних джерел енергії за моделлю Fееd-іп-Preтіит (або контракт на різницю). Окрім альтернативних систем підтримки, гравці ринку також досліджують потенціал розвитку офшорної вітроенергетики та виробництва “зеленого” водню, які стануть невід’ємно частиною не лише розвитку ринку ВДЕ на ринкових механізмах, але й створення нових робочих місць, розвитку національного виробництва та розвитку “зеленоі” економіки. Бібл. 3, табл. 2.

Ключові слова: вітрова енергетика, вітроенергетичний проєкт, механізми підтримки, аукиіони, «зелений» тариф, ринкові умови.

\section{WIND POWER SECTOR OF UKRAINE: THE FURTHER DEVELOPMENT ON MARKET CONDITIONS}

A. Konechenkov, chairman of the Ukrainian Wind Energy Association's Board,

K. Knysh, master, head of Analytical Department of the Ukrainian Wind Energy Association, member of the Public Council at the State Agency for Energy Efficiency and Energy Saving of Ukraine

Public Union Ukrainian Wind Energy Association,

20 Lavrska Street, office 316, 01015, Kyiv, Ukraine

Wind energy is a frontrunner of the global «green» energy transition and wrestler against climate change, which demonstrates its strong resilience to the current global challenges including COVID-19 pandemic. Its impossible to fulfil any international 
commitments as well as to achieve the national climate and energy targets without a clear state energy policy and effective RES support schemes. Current global policy instruments to support renewable energy in general, and wind energy in particular, include regulatory policies, fiscal incentives and public support. All these instruments are used by States in line with their energy capacity, political maturity and economic development. According to the current national legislation, new wind projects put into operation after 2022 are not subject to get a "green» tariff. So the next logical step in the development of Ukraine's carbon neutral economy and the wind industry as well is the transition from «green» tariff to market conditions. Given the Ukrainian political environment, such alternative RES support schemes as «green» certificates, Feed-in premiums, Contract for difference, auctions, corporate PPAs and guarantees of origin are considered as the most preferable for current RES market. Thus, the Ministry of Energy of Ukraine has already taken the first step and in August 2021 presented the Draft Law "On Amendments to Certain Laws of Ukraine on Stimulating the Production of Electricity from Alternative Energy Sources Under Market Conditions" which stipulates for new support scheme for producers of RES electricity namely Feed-in-Premium (or contract for difference). In addition to the above mentioned alternative RES support systems, market players also explore Ukraine's offshore wind power potential as well as the prospects of "green» hydrogen, which will become an integral part not only of the market-based RES sector but also of job creation, development of national manufacture and a "green" economy as a whole. Bibl. 3, table 2.

Keywords: wind power, wind project, RES support schemes, auctions, Feed-in tariff, market conditions.

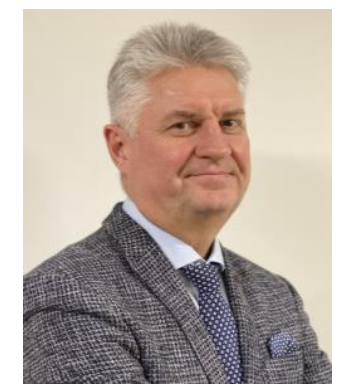

A.С. Конеченков A. Konechenkov
Відомості про автора: голова правління Громадської спілки «Українська вітроенергетична асоціація», віцепрезидент Всесвітньої вітроенергетичної асоціації (WWEA), директор Українського вітроенергетичного агентства. Має 27-річний досвід роботи в секторі відновлюваної енергетики України. У 2018 та 2020 роках нагороджений премією «Екотрансформація» (Еко-Оскар) за вагомий внесок у «зелене» перетворення України. На 18-й Всесвітній вітроенергетичній конференції в Ріо-деЖанейро удостоєний Всесвітньої вітроенергетичної премії 2019 року за видатні досягнення в просуванні вітроенергетики в Україні та світі.

Освіта: Національний технічний університет України «Київський політехнічний інститут імені Ігоря Сікорського». Інженер-механік. Спеціальність «Обладнання та прибори хімічної промисловості»

Наукова сфера: відновлювані джерела енергії та енергозбереження

Публікації: понад 300 публікацій, присвячених відновлюваним джерелам енергії, питанням енергоефективності й енергозбереження

ORCID: 0000-0001-5248-7592

Контакти: +38(067)209-20-65

e-mail: konechenkov@ukr.net
Author information: Chairman of Board of the Ukrainian Wind Energy Association, Vice President of the World Wind Energy Association, Director of the Ukrainian Wind Energy Agency. Mr. Andriy has been working in the renewable energy sector of Ukraine for 27 years. In 2018 and 2020, Andriy Konechenkov was awarded Diplomas «Stakeholder of Green Changes» and Eco-Oscar «Ecotransformation» prize for his significant contribution to the «green» energy transformation of Ukraine. At 18th World Wind Energy Conference in Rio de Janeiro, Andriy Konechenkov received the World Wind Energy Award 2019 for outstanding achievements in the dissemination of wind energy utilization in Ukraine and worldwide

Education: The National Technical University of Ukraine «Igor Sikorsky Kyiv Polytechnic Institute». Mechanical engineer.

Specialty «Equipment and devices for the chemical industry»

Research area: Renewable energy sources and energy savings

Publications: Author of more than 300 publications on renewable energy sources and energy savings

ORCID: 0000-0001-5248-7592

Contacts: $+38(067) 209-20-65$

e-mail: konechenkov@ukr.net 


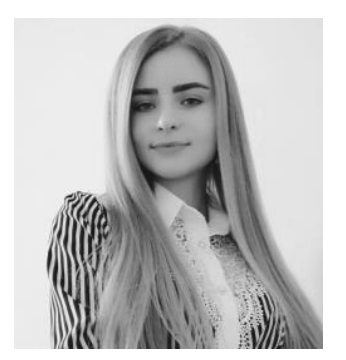

К.О. Книи K. Knysh
Відомості про автора: керівник аналітичного департаменту Громадської спілки «Українська вітроенергетична асоціація», Член Громадської ради при Держенергоефективності. Отримуючи ступінь магістра, вперше в Україні захистила дипломну роботу, присвячену розвитку офшорної вітроенергетики в Україні. У 2021 році, успішно пройшла Програму літньої школи з енергетики при Енергетичному Співтоваристві у Відні, Австрія.

Освіта: Інститут міжнародних відносин Київського національного університету імені Тараса Шевченка. Спеціальність «Міжнародні відносини», напрямок «Екологічна та енергетична безпека»

Наукова сфера: відновлювані джерела енергії та енергетична безпека

Публікації: низка статтей, присвячених вітровій енергетиці, включно з Білою Книгою «Офшорна вітроенергетика та «зелений» водень: відкриття нових меж енергетичної потужності України», підготовленою у співпраці з юридичною фірмою Asters, Українською водневою радою та Інститутом відновлюваної енергетики НАН України

ORCID: 0000-0003-2815-9323

Контакти: +38(099)-71-43-808

e-mail: knyshkatherine@gmail.com
Author information: Head of analytical department of the Ukrainian Wind Energy Association and member of the Public Council at the State Agency for Energy Efficiency and Energy Saving of Ukraine. Kateryna Knysh became the first in Ukraine to defend her Master's diploma on prospects for the development of offshore wind power in Ukraine. Kateryna Knysh has successfully completed 2021 Energy Community Summer School Program in Vienna, Austria.

Education: Institute Of International Relations Taras Shevchenko National University of Kyiv. Specialty «International relations». Programme «Environment and Energy Security»

Research area: Renewable energy sources and energy security

Publications: A number of articles on wind energy, including the White Paper «Offshore wind energy and green hydrogen: new frontiers of Ukraine's energy potential», prepared in collaboration with law firm Asters and Ukrainian Hydrogen Council

ORCID: 0000-0003-2815-9323

Contacts: +38(099)-71-43-808

e-mail: knyshkatherine@gmail.com

\section{Перелік використаних позначень та скорочень:}

ВДЕ - відновлювані джерела енергії;

ВЕС - вітроелектростанція;

ГЕС - гідроелектростанція;

ГеоТЕС - геотермальна електростанція;

ДП - державне підприємство;

кВт·год - кіловат-година;

Вступ. Енергетика - це наріжний камінь існування сучасної цивілізації, що забезпечує економічне зростання, мобільність і комфорт. Електроенергія як частина енергетичної системи $€$ невід'ємною складовою життєдіяльності. Приміром, пандемія COVID-19 чітко продемонструвала, наскільки сильно сучасне суспільство загалом і сектор охорони здоров'я, зокрема залежать від безпечного та стабільного електропостачання. Проте нові кліматичні виклики потребують нових безпечних та ефективних методів реагування, а викопні

\author{
МВт- мегават; \\ МВт·год - мегават-година; \\ НПД - Національний план дій; \\ СЕС - сонячна електростанція; \\ ЗТ - зелений тариф; \\ ЗМІ - засоби масової інформації.
}

джерела енергії, що продукують значні викиди парникових газів, підлягають оперативному заміщенню відновлюваними джерелами енергії.

Вітрова енергетика як один із різновидів відновлюваних джерел енергії $\epsilon$ найефективнішим та найбезпечнішим інструментом скорочення викидів парникових газів та досягнення цілей Паризької Угоди. Проте виконання взятих на себе міжнародних зобов'язань і досягнення національних цілей 3 розвитку відновлюваних джерел енергії неможливі без структурованої державницької 
позиції та ефективних механізмів стимулювання проєктів ВДЕ, як, наприклад, «зелений» тариф. Згідно з чинним законодавством України нові вітроенергетичні проєкти, введені в експлуатацію після 2022 року, не зможуть отримати «зелений» тариф. Саме тому перехід від «зеленого» тарифу до альтернативних механізмів підтримки $є$ логічним наступним крокому у розвитку національного вітроенергетичного сектора та розбудови безвуглецевої економіки України.

Мета і завдання. Метою даної статті $\epsilon$ окреслення сучасних механізмів підтримки ВДЕ й висвітлення потенціалу їх застосування в Україні.

Відповідно до поставленої мети мають бути виконані такі завдання:

1. Аналіз сучасних механізмів підтримки ВДЕ та рівня їх застосування у світі.

2. Окреслення сучасного стану розвитку сектора вітрової енергетики України.

3. Визначення рівня виконання Національного плану дій 3 відновлюваної енергетики до 2035 року.

4. Визначення проблем застосування «зеленого» тарифу в Україні.

5. Висвітлення перспектив розвитку сектора вітрової енергетики на ринкових умовах.

Виклад основного матеріалу. Ратифікувавши Паризьку Угоду в 2016 році, Україна стала однією 3 перших країн, яка на міжнародному рівні підтвердила своє прагнення розвивати відновлювані джерела енергії та переходити на безвуглецеву економіку. Енергетичні та кліматичні зобов'язання України також підтверджені дійсним членством у Енергетичному Співтоваристві та схваленими Урядом України Національним планом дій 3 відновлюваної енергетики, який передбачав досягнення 11\%-ї частки ВДЕ (включно з ГЕС великої потужності) у національному обсязі електрогенерації до 2020 року, та Енергетичною стратегією України, відповідно до якої частка ВДЕ в національному енергобалансі України має сягнути $25 \%$ до 2035 року (з урахуванням ГЕС великої потужності).

Сьогодні сектор вітрової енергетики залишається другим в країні за кількістю встановлених потужностей серед усіх відновлюваних джерел енергії. Станом на кінець 2020 року загальна потужність вітроенергетичного сектора України досягла 1 176,1 МВт (без урахування ВEC на тимчасово окупованих територіях), а частка вітроенергетики у загальній встановленій потужності національного сектора ВДЕ склала 15,4 \%. За минулий рік вітроенергетичні потужності поставили до об'єднаної енергосистеми України 3 251,6 млн кВт·год «зеленої» електроенергії, що достатньо для забезпечення електроенергією понад 650000 українських домогосподарств 3 середньомісячним споживанням електроенергії на рівні 500 кВт·год. Завдяки генеруванню чистої електроенергіï ВЕС щорічні викиди вуглецю в країні у 2020 році були знижені на 2,6 млрд тонн, що підтверджує критично важливу роль вітрової енергетики у досягненні глобальних кліматичних цілей зі скорочення викидів $\mathrm{CO}_{2}$.

Сучасними світовими політичними інструментами підтримки відновлюваних джерел енергії загалом та вітрової енергетики зокрема $є$ регуляторна політика, податкові стимули та державна (фінансова) підтримка. Всі ці інструменти на практиці реалізуються у вигляді окремих механізмів підтримки, які 
використовуються країнами відповідно до їх енергетичної спроможності, політичної зрілості та економічної розвиненості. На сьогодні існує декілька механізмів підтримки розвитку відновлюваних джерел енергіі:

- «зелений» тариф (англ. Feed-in tariff);

- «зелені» сертифікати;

- «зелені» надбавки (англ. Feed-in premiums); контракти на різницю (англ. Contract for difference);

- Аукціони;

- прямі договори купівлі-продажу електроенергії (англ. Corporate PPAs);

- Гарантії походження електроенергії.

Разом 3 вищепереліченими механізмами також можуть застосуватися тендери, податкові пільги, інвестиційні гранти й позикові гарантії. Різні підходи до застосування цих механізмів підтримки можуть, 3 одного боку забезпечити збалансований та поступовий розвиток «зеленої» генерації зі стабільним прибутком, проте, 3 іншого боку, розбалансувати ринок, підірвати довіру інвесторів і навіть призупинити розвиток сектора відновлюваних джерел енергії в країні, яскравим прикладом чого, на жаль, є досвід України.

Найпоширенішими механізмами розвитку відновлюваних джерел енергії є «зелений» тариф, «зелені» сертифікати та «зелені» надбавки. «Зелений» тариф (ЗТ) сьогодні застосовується в понад 50 країнах світу і $\epsilon$ тим механізмом, в рамках якого держава зобов'язується викуповувати всю вироблену за рахунок ВДЕ електроенергію за фіксованим тарифом. Сьогодні завдяки зрілості технологій та скороченню їх вартості ВДЕ вже конкурують 3 викопними енергоносіями на розвинутих енергетичних ринках світу. Водночас у світі існують прецеденти, коли при такому механізмі розмір 3Т для одного виду генерації ВДЕ більше розміру ЗТ для іншого виду, що спричинює як фінансовий, так i проєктний дисбаланс на ринку. Тому сьогодні спостерігається глобальна тенденція до переходу від «зеленого» тарифу до тих механізмів, які створюють справедливу конкуренцію між учасниками ринку. Україна не є винятком у цьому процесі.

Привабливим для виробників 3 ВДЕ $\epsilon$ механізм «зелених» надбавок. В рамках цього механізму підтримки виробники з ВДЕ продають вироблену електроенергію на ринку за загальними правилами, додатково отримуючи надбавку за кожну продану кіловат-годину електроенергії. Тим самим держава стимулює виробників з ВДЕ генерувати більше «зеленої» електроенергіï, а виробникам 3 ВДЕ надається можливість продавати електроенергію за ціною вище ринкової, що створює відповідну конкуренцію на ринку. До того ж «зелені» надбавки можливі двох типів: фіксована та змінна (коли вартість надбавки змінюється залежно від виду генерації чи потужності об 'єкma).

Одним iз механізмів, який стимулює найбільшу конкуренцію між учасниками ринку вважається контракт на різницю. Цей механізм дає змогу виробникам 3 ВДЕ продавати електроенергію за ринковими цінами, додатково укладаючи договір 3 державою, що гарантує компенсацію різниці між встановленим тарифом і ринковою ціною. Компенсація відбувається у двосторонньому порядку: як державою виробникам з ВДЕ (якщо тариф на ринку нижче рівня відшкодування), так і виробниками з ВДЕ 
державі (якщо тариф на ринку вище рівня відшкодування). Даний механізм успішно застосовується Сполученим Королівством та Албанією.

Найпоширенішим механізмом, до якого відбувається перехід від «зеленого» тарифу, є прямі договори

купівлі-продажу

електроенергії або так звані корпоративні РPA. Корпоративні PРА є довгостроковим договором купівлі-продажу електричної енергії з ВДЕ, який передбачає купівлю «зеленої» електроенергії не конкретно визначеним державним підприємством (яким, наприклад виступає ДП «Гарантований покупець» в Україні), а приватними компаніями. Відповідно, цей договір дозволяє регулювати цінову пропозицію між виробниками та споживачами електроенергії. Такі договори вже успішно укладені світовими корпораціями, як-от Apple, Google, Amazon, які заявили свої амбіції щодо 100\%-го переходу на відновлювані джерела енергії.

Система гарантій походження. Згідно 3 Законом України №2019-VIII «Про ринок електричної енергії» від 13.04.2017 на підтвердження походження електричної енергії, на запит виробника, може видаватись гарантія походження електричної енергії - документ, який видає Державне агентство 3 енергоефективності та енергозбереження України відповідно до Порядку видачі, використання та припинення дії гарантії походження електричної енергії для суб'єктів господарювання, що виробляють електричну енергію 3 альтернативних джерел енергії. Гарантія видається в електронному вигляді на безоплатній основі на певний обсяг відпущеної в електричну мережу електричної енергії для кожної генерувальної установки окремо та на кожний вид джерела енергії. При цьому обсяг визначається 3 точністю до 1 МВт·год і діє протягом 12 місяців 3 дня видачі. Проте де-факто в Україні даний механізм не працює.

Усі вищезгадані механізми підтримки можуть успішно застосовуватись у комбінації 3 аукціонною моделлю підтримки ВДЕ. На аукціонах виробники 3 ВДЕ фактично «змагаються» за право отримати фінансову підтримку держави. Так, держава формує квоти на нові проєкти, а виробники з ВДЕ відповідно до оголошених квот надають свої пропозиції, які включають потужність майбутнього об'єкту та потенційну ціну продажу згенерованої ним електроенергії. За результатами аукціону право на державну підтримку отримує той виробник, який надає найпривабливішу пропозицію. Аукціони $\epsilon$ найпоширенішим сьогодні механізмом підтримки ВДЕ, який застосовується у 106 країнах світу.

3 квітня 2009 року відновлювані джерела енергії в Україні розвиваються завдяки існуванню «зеленого» тарифу, що регулюється Законом України №555-IV «Про альтернативні джерела енергії». Проте первинною метою запровадження «зелених» тарифів для окремих бізнес-груп стало не стільки прагнення розвивати відновлювані джерела енергії, скільки прагнення отримати надприбуток. Тому розміри ЗТ для різних видів суттєво відрізнялись, 3 великим перекосом в бік сонячної генерації, встановлений тариф на яку не мав економічного підгрунтя. Це, 3 одного боку, спричинило безпрецедентне зростання сектора відновлюваної енергетики за рахунок різкого будівництва сонячних електростанцій, проте, з іншого боку, призвело 
до незбалансованого розвитку інших видів «зеленої» генерації. Результат такої непродуманої державної підтримки відновлюваних джерел енергії яскраво підтверджується рівнем виконання вищезгаданого Національного плану дій 3 відновлюваної енергетики до 2020 року (НПД), в якому Урядом України була закладена чітка ціль 3 розвитку ВДЕ в країні, яка до 2020 року передбачала введення в експлуатацію 2280 МВт вітрових потужностей, $2300 \mathrm{MBT}$ сонячних потужностей, $5200 \mathrm{MB}$ гідроенергетичних потужностей, $950 \mathrm{MBT}$ біоенергетичних потужностей та $20 \mathrm{MB}$ потужностей геотермальної енергетики.

\section{За результатами 2020 року можна} констатувати, що хоча частка «зеленої» генерації в загальному обсязі електроенергії в країні, 3 табл. 1.

урахування ГЕС великої потужності, і досягла запланованих $11 \%$, проте цілі НПД України за встановленою потужністю станцій 3 ВДЕ перевиконані на $18 \%$ саме за рахунок різкого розвитку сонячної генерації. Так, на кінець 2020 року загальна встановлена потужність сектора сонячної енергетики досягла $6872,6 \mathrm{MB}$ (з урахуванням 779 MBт сонячних систем домашніх домогосподарств) проти запланованих 2300 МВт, що втричі більше від цілі, поставленої НПД. Водночас 1314,1 MBт загальної встановленої вітроенергетичної потужності, 3 урахуванням $138 \mathrm{MBT}$, що знаходяться на територіях ОРДЛО, замість запланованих 2280 МВт свідчать про 57 \% виконання цілей НПД сектором вітрової енергетики.

Незбалансованість розвитку потужностей різних видів генерації з ВДЕ детальніше наведена в

Таблиця 1. Стан виконання Національного плану дій з відновлюваної енергетики до 2020 року

Table 1. Implementation of the National Renewable Energy Action Plan by 2020

\begin{tabular}{|c|c|c|c|c|c|c|c|c|c|c|}
\hline ВДЕ/рік & \multicolumn{2}{|c|}{2009} & \multicolumn{4}{|c|}{2019} & \multicolumn{4}{|c|}{2020} \\
\hline & MBT & $\begin{array}{c}\text { млн } \\
\text { кВт·год }\end{array}$ & MBт & $\begin{array}{c}\text { млн } \\
\text { кВт·год }\end{array}$ & МB $\mathbf{T}$ & $\begin{array}{c}\text { млн } \\
\text { кВт·год }\end{array}$ & МВт & $\begin{array}{c}\text { млн } \\
\text { кВт•год }\end{array}$ & МBт & $\begin{array}{c}\text { млн } \\
\text { кВт·год }\end{array}$ \\
\hline & \multicolumn{2}{|c|}{ фактично } & \multicolumn{2}{|c|}{ За НПД } & \multicolumn{2}{|c|}{ фактично } & \multicolumn{2}{|c|}{ За НПД } & \multicolumn{2}{|c|}{$\begin{array}{c}\text { Фактично станом на } \\
31.12 .2020\end{array}$} \\
\hline $\begin{array}{c}\text { МГEC: } \\
<1 \mathrm{MBT} \\
-10 \mathrm{MBT} \\
\end{array}$ & 49 & 30 & 138 & 310 & 114 & 241,5 & 150 & 340 & 116,8 & 219,9 \\
\hline $\begin{array}{c}\text { ГEC }>10 \\
\text { MBT }\end{array}$ & 4500 & 11400 & 5120 & 12800 & 4639,3 & 6521,9 & 5200 & 13000 & 4639,3 & 6025,5 \\
\hline ГeoTEC & 0 & 0 & 17 & 105 & 0 & 0 & 20 & 120 & 0 & 0 \\
\hline $\mathrm{CEC}$ & 0 & 0 & 2000 & 2100 & 4924,6 & 2932,4 & 2300 & 2420 & $\begin{array}{c}6872,6 / \\
6093,6 \\
\text { без дом }\end{array}$ & 6604,6 \\
\hline $\begin{array}{c}\text { ВEC } \\
\text { наземні }\end{array}$ & 76 & 41 & 2100 & 5460 & 1169,9 & 2021,7 & 2280 & 5900 & 1314,1 & 3251,6 \\
\hline $\begin{array}{c}\text { Енергія } 3 \\
\text { біомаси }\end{array}$ & 0 & 0 & 780 & 3450 & 170,1 & 409,8 & 950 & 4220 & 212,1 & \\
\hline тверда & 0 & 0 & 540 & 2415 & 84 & 162,4 & 660 & 2950 & 108,7 & 150,3 \\
\hline біогаз & 0 & 0 & 240 & 1035 & 86,1 & 247,4 & 290 & 1270 & 103,4 & \\
\hline УСБОГО: & 4625 & 11471 & 10155 & 24225 & 11007,9 & 12127,3 & 10900 & 26000 & 13154,9 & 16851,2 \\
\hline
\end{tabular}


Різке зростання сонячної генерації стало лише початком тих проблем, 3 якими стикнувся ринок електричної енергії України у зв'язку з непослідовною державною політикою 3 ВДЕ. В липні 2019 року в Україні запрацювала нова оптова модель ринку електричної енергії, яка засновується на п'яти окремих сегментах ринку: ринку двосторонніх договорів, ринку «на добу наперед», внутрішньодобовому ринку, балансувальному ринку та ринку допоміжних послуг. Передбачалось, що нова модель ринку створить більшу конкуренцію між учасниками ринку та сприятиме прозорості його функціонування, зокрема завдяки впровадженню «зелених» аукціонів.

Натомість новий ринок лише ще більше масштабував усі недоліки діючої в країни системи підтримки ВДЕ, оскільки бурхливий розвиток «зеленої» електроенергетики у 2019 році, здебільшого сонячної, окрім дисбалансу балансувальних потужностей спричинив ще й фінансовий дисбаланс, пов'язаний 3 непередбачуваними витратами на закупівлю «зеленої» електроенергії. Після декількох спроб законодавчо врегулювати ситуацію на ринку 9 грудня 2019 року Українська вітроенергетична асоціація та Європейсько-українське енергетичне агентство ініціювали при Центрі вирішення спорів та переговорів Секретаріату Енергетичного Співтовариства медіацію спору між інвесторами у ВДЕ та Урядом України. За результатами переговорів, які тривали 8 місяців, сторони підписали Меморандум про Взаєморозуміння щодо врегулювання проблемних питань у сфері відновлюваної енергетики України, відповідно до якого інвестори з ВДЕ добровільно погодились на реструктуризацію «зеленого» тарифу для існуючих та нових енергогенерувальних об'єктів відновлюваної енергетики. Згодом досягнуті домовленості були узаконені прийнятим Верховною Радою України Законом України №810-IX «Про внесення змін до деяких законів України щодо удосконалення умов підтримки виробництва електричної енергії 3 альтернативних джерел енергії».

Навіть незважаючи на добровільну реструктуризацію «зелених» тарифів та відповідне полегшення фінансових зобов'язань ДП «Гарантований покупець» перед виробниками 3 ВДЕ, національний ринок відновлюваних джерел енергії досі перебуває в кризі як фінансового, так і технічного характеру:

- Виробники з ВДЕ досі очікують виплати заборгованості ДП «Гарантований покупець» за поставлену в мережу «зелену» електроенергію.

- Досі затримується впровадження «зелених» аукціонів в Україні. Проте навіть у разі їх запуску презентовані Міністерством енергетики України квоти підтримки, особливо для сектора вітрової енергетики України, $€$ мізерними для того, щоб компенсувати втрачені інвесторами ВДЕ фінансові можливості від скорочення «зеленого» тарифу. Для порівняння: відповідно до даних WindEurope, в Свропі у 2020 році було успішно розіграно на аукціоні 7411 МВт вітроенергетичних потужностей, тоді як в Україні для сектора вітрової енергетики Міністерством енергетики було запропоновано лише 150 МВт для аукціонів 2021 року (табл. 2), та 800 МВт - для аукціонів на 2022-2025 роки.

- Відновлювані джерела енергії, і вітрова енергетика в тому числі, досі розвиваються під тиском лобістів традиційних джерел енергії. Так, 
17 липня 2020 року 47 народних депутатів України скерували до Конституційного Суду України конституційне подання про визнання неконституційним механізму «зелених» тарифів. Станом на кінець березня 2021 року Конституційний Суд України досі не виніс рішення в цій справі, через що реалізація окремих вітроенергетичних проєктів призупинена. Окрім того, до Антимонопольного комітету України було надіслано запит щодо незаконної державної підтримки сектора ВДЕ України. Цей список реальних прикладів енергії. політичного тиску на сектор ВДЕ в Україні не є вичерпним і може бути продовжений випадками перевірок компаній з ВДЕ Податковою службою України та багатьма випадками поширення неправдивої та маніпулятивної інформації в 3МІ.

- На додаток до цього на рівні Уряду України досі заморожене питання про розвиток маневрових та балансувальних потужностей та систем акумулювання й накопичення енергії в країні, які є критично важливими для стабільного та безпечного розвитку відновлюваних джерел

Таблиця 2. Графік проведення аукціонів на 2021 рік, МВт

Table 2. Auctions schedule for 2021, MW

\begin{tabular}{|c|c|c|c|c|c|c|c|c|c|c|c|c|c|c|}
\hline \multirow{2}{*}{ Вид } & \multirow{2}{*}{ Тип } & \multicolumn{12}{|c|}{ Місяць } & \multirow{2}{*}{ Всього } \\
\hline & & 1 & 2 & 3 & 4 & 5 & 6 & 7 & 8 & 9 & 10 & 11 & 12 & \\
\hline \multirow{3}{*}{ CEC } & Загальний & & & & & & 50 & & & & & 50 & & 100 \\
\hline & До $1 \mathrm{MBT}$ & & & & & & & & & & 5 & & & 5 \\
\hline & Регіональний & & & & & & & & & & 50 & & & 50 \\
\hline $\mathrm{BEC}$ & Загальний & & & & & & 50 & & & & & 100 & & 150 \\
\hline Інші & Загальний & & & & & & & & & & 60 & & & 60 \\
\hline & & & & & & & 100 & & & & 115 & 150 & & 365 \\
\hline
\end{tabular}

Зважаючи на вищеперелічені проблеми та на 5600 МВт вітроенергетичних проєктів, які станом на кінець грудня 2019 року отримали дозволи на будівництво, саме перехід від «зеленого» тарифу до ринкових умов надасть новий поштовх подальшому розвитку відновлюваної енергетики в країні.

Висновок. Розглядаючи потенційну можливість впровадження запропонованих вище альтернативних систем підтримки, можна констатувати, що українське законодавство наразі не передбачає спеціального регулювання щодо корпоративних РРА, «зелених» надбавок чи контрактів на різницю, не діє система Гарантій походження. Для їх запровадження $є$ потреба ухвалити відповідні нормативні зміни й удосконалити чинне законодавство. Крім того, Кабінету міністрів України необхідно визначити квоти підтримки проєктів ВДЕ i нарешті провести аукціони з ВДЕ. Функціонування ринку вітрової енергетики на конкурентних засадах може не лише сприяти підвищенню конкуренції між учасниками ринку, але й зробити сектор більш незалежним від держави, особливо від іi 
непродуманої енергетичної політики. Зацікавленою аудиторією статті виступають як галузеві державні органи влади, так і дійсні учасники ринку відновлюваних джерел енергії. Практичне значення здійсненого аналізу потенційних механізмів підтримки ВДЕ в Україні визначається можливістю подальшої розробки Концепції 3 розвитку відновлюваних джерел енергії загалом та вітрової енергетики зокрема після закінчення дії «зеленого» тарифу в Україні.

1. Бабаєв М. Україна після «зеленого» тарифу. Нові механізми розвитку відновлюваної енергетики. 2021.39 с.

2. Конеченков А.С., Книш К. О., Шмідт Г.Б., Гріцишиина М. С. та ін. Вітроенергетичний сектор України 2020. Огляд Ринку. 2021. 82 с.
3. Вітрова енергетика в Європі у 2020 році: статистка та прогноз на 2021-2025 роки. [Wind Energy in Europe 2020 statistics and the outlook to 2021-2025].

\section{REFERENCES}

1. Babayev M. Ukrayina pislya zelenoho taryfu. [Ukraine after the "green" tariff. New RES support schemes]. Novi mekhanizmy rozvytku vidnovlyuvanoyi enerhetyky. 2021. 39 p. [in Ukrainian].

2. Konechenkov A., Knysh K., Shmidt G., Hritsyshyna M. Vitroenerhetychnyy sektor Ukrayiny 2020. [Wind power sector of Ukraine 2020.]. Ohlyad Rynku. 2021. 82 p.

(Applying date: 13.03.2021). [in Ukrainian].

3. Vitrova enerhetyka v Yevropi u 2020 rotsi: statystyka i prohnoz na 2021-2025 roky. [Wind Energy in Europe 2020 statistics and the outlook to 2021-2025].

(Applying date: 13.03.2021). [in English].

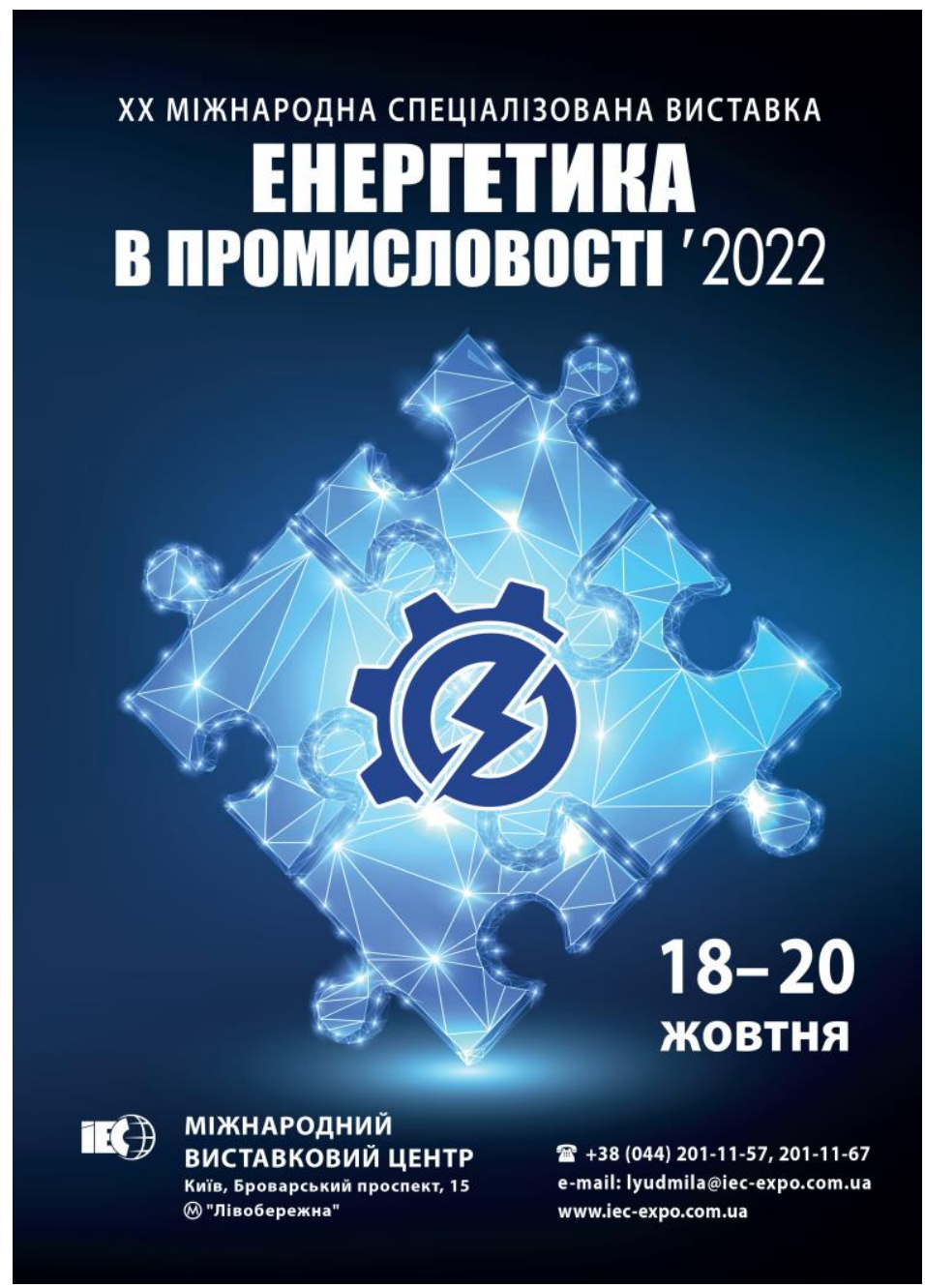

Остаточна версія 02.12.21 